Journal of Islamic Monetary Economics and Finance, Volume 3, Special Issue, 2018, pp 1 - 24

p-ISSN: 2460-6146, e-ISSN; 2460-6618

\title{
LINKING ISLAMIC COMMERCIAL AND SOCIAL FINANCE WITH SPECIAL REFERENCE TO CASH-WAQF AS NEW STRATEGY OF INTEREST-FREE MICRO-CREDIT FOR FAMILY EMPOWERMENT OF THE POOR TOWARDS ESTABLISHING WORLD SOCIAL BANK: A CASE STUDY APPROACH
}

\author{
M.A. Mannan ${ }^{1}$
}

\begin{abstract}
The floating of Cash-waqf Certificate as a financial instrument by Social Islami Bank Ltd (SIBL) in Bangladesh in 1997 (formerly known as Social Investment Bank Ltd) is an innovation in the history of Islamic Finance. The issuance of Cash-waqf Certificate has settled the age-old controversy among scholars concerning the concept of perpetuity and inalienability associated with waqf property since its implementation during the Ottoman Empire in the early 15th century. This study has put forward three proposals to establish a World Social Bank that includes (i) Giving Institutional Leadership by Bank Indonesia (ii) Forming International Taskforce (iii) Connecting Initiatives of MuslimMinorities in Non-Muslim Countries for initial establishment of Commonwealth of Human Communities. Since the aforementioned Cash Waqf is managed by the Bank, it has its transparency and accountability, it is a perpetual deposit and its profit can be invested in a wide spectrum of social investment. Bank shall manage Cash-Waqf on behalf of the Waqif. It can help monetizing Islamic Voluntary Sector, accumulation of Social Capital and National wealth, implementing strategic social investment program that reinforces family values, family heritage empower people at grass roots and stimulates economic, social and moral foundation of a caring society. Cash-Waqf Certificate provides new opportunities to transfer liquid asset and make connection with one another on a global scale leading to establishment of World Social Bank a new strategy of interest-free micro-credit for empowering the poor to irrespective of caste, creed and religion.
\end{abstract}

Keywords: Islamic Social Finance, Waqf, Cash Waqf, Community Empowerment. JEL Classification: D91, I31, P36

Received : October 28, 2017

Revised : July 24, 2018

Accepted : August 1, 2018

1. Founder Chairman, Social Islami Bank Ltd. (SIBL), Dhaka, Bangladesh and House of Mannan Charitable Trust (HMCT), Email: mannan@islamibankbd.com 


\section{EXECUTIVE SUMMARY}

The floating of Cash-waqf Certificate as a financial instrument by Social Islami Bank Ltd (SIBL) in Bangladesh in 1997 (formerly known as Social Investment Bank Ltd) is an innovation in the history of Islamic Finance. The issuance of Cash-waqf Certificate has settled the age-old controversy among scholars concerning the concept of perpetuity and inalienability associated with waqf property since its implementation during the Ottoman Empire in the early 15th century. Cash-waqf Certificate solved the Ottoman dilemma for the first time in history by removing the twin barriers of waqf to perpetuity, and immovable property endowment as well as Islamic injunctions on charging interest on loan. It provided an opportunity for Muslims to invest in religious, educational or other social development.

The banking industry in Bangladesh that includes at least six Islamic Banks has continued using cash waqf as their investment products. The collecting cash from the public through Cash-waqf Certificate breaks the age-old monopoly of the rich for waqf establishment. Indeed, for the first time small savers can contribute in form of Cash-waqf. Theoretically, the number of cash waqf certificate holders can now be infinite. Each certificate can be issued in terms of a small denomination worth US 1 (one) dollar. To make contributions even more affordable, cash-waqf certificates as issued by Social Islami Bank can also be purchased in installments. It is distinctly different from the management of Zakah, Foundation, Trust, Charities in our societies.

The revenue generated from cash waqf fund can be used to implement strategic social investment program providing interest-free family empowerment micro-credit to the poor thereby a link between Islamic commercial finance and social finance. Credit can transfer power to powerless and help alleviate poverty. It can reinforce power of the powerful and help in concentration and inequitable distribution of income and thus aggravating the poverty. Seen from this prospective, it can empower a family or disintegrate it. The family is a basic foundation of human society. Cash-waqf Certificate can connect people at grassroots, reinforce family values, provides new opportunities to transfer liquid asset as well as make connection with one another on a local, national and global scale. Paper stressed the need for local, national and global mobilization of Cash-waqf fund for establishment of World Social Bank to open up new frontiers of human freedom from economic, educational and social deprivations that includes provisioning for interest-free family empowerment micro-credit to the poor.

Based on the report published by Pew Forum on Religion and Public Life (2007), the global Muslim population stands at 1.6 billion, meaning that nearly 1 in 4 people in the world practice Islam. The Report also presents a portrait of the Muslim world that might be an eye-opener to those who read it. For instance, Germany has more Muslims than Lebanon, China has more Muslims than Syria, Russia has more Muslims than Jordan and Libya combined, and Ethiopia has nearly as many Muslims as Afghanistan. With 2.1 billion followers, Islam is world's second largest religion after Christianity. Moreover, one-fifth of the world's Muslim population is living in countries where Islam is not the majority religion.

Based on these statistics, various Simulation Mode1s can be constructed based on different assumptions. Assuming mobilization of Cash- Waqf of one US dollar per Muslim in one month amounts to accumulation of about 1.6-billion-dollar 
cash-Waqf fund globally, 224 million in Indonesia, 160 million in Bangladesh, 154 million in Pakistan, 70 million in Turkey, 25 million US dollar in Malaysia and so on.

Muslims are the only major religious group projected to increase faster than the world's population as a whole estimated change in population size, 2010-2050 is Muslims: 73\%, Christians: 35\%, Hindus: 34\%, Jews: 16\%, Folk Religions: 11\%, Unaffiliated: $9 \%$, Other Religions: $6 \%$, Buddhists: -0.3 , and 35\% growth in overall global population.

This study has put forward three proposals to establish World Social Bank that includes (i) Giving Institutional Leadership by Bank Indonesia (ii) Forming International Taskforce (iii) Connecting Initiatives of Muslim-Minorities in Non-Muslim Countries for initial establishment of Commonwealth of Human Communities. Nation-state's concept has generated crisis, conflict and war in the affairs of mankind. Cash-waqf can be spent for the welfare of non-Muslim also. Since the establishment of World Bank almost 73 years ago in 1944, World Bank has failed to alleviate poverty. Indeed, World Bank has helped institutionalizing poverty as an international business. According to Oxfam (2016), the richest 1\% own wealth equals to that of $99 \%$ world population (The Daily Star, 2016).

\section{STUDY OBJECTIVES}

The Key thrust of the paper is to unfold the limitless opportunities and possibilities of Cash-waqf Certificate as issued by Social Islami Bank Ltd (SIBL) (previously known as Social Investment Bank Ltd) in 1997 as an innovation in the history of Islamic (Mannan, 1999). Finance. In this context, the paper provides an overview of the conceptual framework of waqf and Cash-waqf as well as provide a brief of historical perspective of Waqf in Islam in general and Bangladesh in particular.

The issuance of Cash-waqf Certificate by SIBL has settled the ageold controversy among scholars concerning the concept of perpetuity and inalienability associated with waqf property since its implementation during the Ottoman Empire in the early 15th century (Ibrahim, et al., 2013). The concept of perpetuity and inalienability means that once a property, often real estate, is immovable and dedicated as a waqf forever. But the terminology of cash-waqf could be understood as a moveable or alienable concept compared to other waqf. Besides, endowments of Cash-waqf generated revenue through interest bearing loans during the Ottoman Economy. Scholars have therefore debated that cashwaqf contravenes the waqf tradition of immovable property and perpetuity as well as Islamic injunctions against charging interest on cash-waqf.

Cash-waqf Certificate of Social Islamic Bank solved the Ottoman dilemma for the first time in history by removing the twin barriers of waqf to perpetuity, and immovable property endowment as well as Islamic injunctions on charging interest on loan. Thus, cash-waqf certificate provides an opportunity for Muslims to invest in religious, educational or other social development. The banking industry in Bangladesh that includes at least six Islamic Banks has continued using cash waqf as their investment products. The collecting cash from the public through Cash-waqf Certificate breaks the age-old monopoly of the rich for waqf establishment. Indeed, for the first time small savers can contribute in form of 
cash-waqf. Theoretically, the number of cash waqf certificate holders can now be infinite. Each certificate can be issued in terms of a small denomination worth even US 1 (one) dollar. To make contributions even more affordable, cash certificates issued by Social Islami Bank in Bangladesh can also be purchased in installments (Cizakca, 2011). Cash-waqf is distinctly different from the management of Zakah, Foundation, Trust, Charities in our societies. Revenue generated from cash waqf fund can be used to implement strategic social investment program providing interest-free family empowerment micro-credit to the poor as well as profitable investment options for the rich thereby linking Islamic commercial finance and social finance (Mannan, 2011). Cash-waqf Certificate can then connect people at grassroots, reinforce family values, provides new opportunities to transfer liquid asset as well as make connection with another on a local, national and global scale to open up new frontiers of human freedom from economic, educational and social deprivations that includes provisioning for interest-free micro-credit to the poor.

This is indeed a paradigm shift in micro-financing for reducing the human poverty in Bangladesh in particular, and world in general. Ideas die without institution. Therefore, establishment of World Social Bank as a collective response of the Ummah is the need of the hour. At the end, paper has put forward an Action Plan.

\section{AWQAF AND CASH-WAQF: AN OVERVIEW OF THE CONCEPTUAL FRAMEWORK}

The word Waqf (p1. Awqaf) comes from a root meaning "to prevent or restrain". In Arabic, it literally signifies "confinement or detection". As the terminology of Islamic jurisprudence, it may be defined as an act of refraining from the use and disposal of any asset from which one can benefit or use its proceeds for any charitable purpose as long as it exists. In fact, the vast majority of Hanafi scholars regard Waqf as "taking the corpus of any property out of ownership of Allah and dedicating its usufruct to others". In the language of the contemporary law, Waqf does signify the usufructuary donation, made in favor of a beneficiary, with a view to fulfillment of some pious aim or some projects of general utility and which entailed the legal sequestration of gift or donation, whether this donation included, did not include, a usufruct". It is also defined as "non-negotiable properly dedicated to charitable purposes, once for all", or as "the permanent dedication by a person professing the Musalman faith of any properly for any purpose recognized by the Musalman law as religious, pious or charitable".

Following up these definitions, we can say that "by Waqf (pl. Awqaf) is meant a property, which, while retaining its substance, yields a usufruct of which the owner has surrendered his power of disposal with the stipulation that the yield is used for permitted purposes. Waqf really means, however, the legal process by which one creates such an endowment (synonymous with tahbis, tasbil or tahrin)."

\subsection{Cash Waqf, Sadaqah and Gifts}

From the very nature of its transaction, Cash Waqf may be seen as a kind of Sadaqah. But what distinguishes it from Sadaqah is that in the case of Sadaqah, 
the substance is transferred and also the profits but in Cash Waqf, the substance is retained but the profits go to the beneficiaries of the Cash Waqf thereby providing link between Islamic corporate finance and social finance. Similarly, the difference between Waqf and gift is that, in the case of a gift, the substance is transferred from one person to another person and without consideration but a Cash Waqf is for a consideration, the same being religious merit. Clearly, Cash Waqf revenue cannot be regarded as zakat which is obligatory, and its eight heads of expenditure are specified in the Holy Qur'an.

\subsection{Waqf and Trust}

It should be noted here that a Waqf must also be distinguished from Trust. In a Waqf, the property is vested in Allah, while in a Trust it is vested in the trustee. Unlike a Cash Waqf in a Trust, it is not necessary that a Trust must be perpetual, irrevocable or inalienable or made with a pious or religious motivation. Cash Waqf can, however, be created in favor of both affluent and indigent alike or in favor of family or indigent exclusively, although pious and religious motive becomes predominant concern of Awqaf endowments. Thus, according to all schools, a Cash Waqf may be created for the benefit of any person or class of persons or for the service or well-being of humanity, although a founder may make his own maintenance for life a first charge on the income of the Cash Waqf All the schools of Shari'ah have, however, stressed the importance of the creation of a Waqf which had played an important role in alleviating poverty and in furthering learning in the past and it is expected to play its role in the future provided this institution is re-activated and its management is placed on the sound footing.

\section{WAQF IN ISLAM: A BRIEF HISTORICAL PERSPECTIVE}

The very development of Waqf as an Institution in Islam and its legitimacy can be deduced from the Quranic repeated "exhortation at a number of places, and in different ways and contexts to render voluntary economic assistance to the fellowbeings and the poor as well as from various traditions of the Prophet (Peace be upon him). In fact, the positive evidences of the legitimacy of the Institution of Waqf can implicitly be found in the Qur'anic verse in Sura A1-lmran which says: "You shall not receive godliness unless you spent out of that which is dear to you". Again, the Prophet (Peace be upon him) is reported to have said that "a man's work ends upon his death except for three things: (a) on-going charity, (b) contribution to knowledge and (c) faithful child praying for him". Here the Institution of Waqf is seen by scholars as an on-going charity.

Throughout the history of Islam, Waqf played a crucial stance in promoting, social, economic and cultural activities of Muslim communities and provided scholars with secure means of livelihood, thereby providing them an opportunity to engage in research and schooling in a manner which made them independent of Government's and the ruling class. In fact, it did perform the duties of numerous Government institutions or specialized ministries of our contemporary period, such as Ministries of Health, Education and Social Welfare. 
The first Waqf in Islam was "Quba Mosque near Madina", which was established by Prophet Muhammad (peace be upon him). The second Waqf was the Prophet's mosque in Madina - Dar Al Hijra, which was built by the Prophet (Peace be upon him) and also reported to have made the first Waqf for charitable purposes after he look over the possession of the seven gardens of one Mukhairaiq in accordance with his desire and endowed them as such. Mukhairaiq who was a Jew was reported to have been killed while he was fighting on the side of the Muslims in the battle of Uhud. This was followed by the endowments of Umar and other companions like Abubakar, Osman, Ali and others.

However, the study of actual Waqf administration provides many valuable details not only about its uses but also its abuses. Mismanagements and embezzlements of Waqf funds were not rare. As a result, various administrative strategies were adopted to achieve the objectives for which the Waqf was made. Thus, varieties of agreements were created not only for the letting of Waqf estates but also for granting perpetual leases, adopted to the institution of Waqf 'Since the 16th century, in contrast to temporary leases of three years, perpetual leases were granted in some cases to encourage personal incentives in the management and keep up the Waqf, as in some cases, the condition of the Waqf possessions deteriorated so much that the revenues were not even sufficient for the necessary maintenance of the properties, not to speak of benefiting the poor, or achieving the objectives for which the original endowment was made. Under these perpetual leases, particularly in Turkey and Egypt, tenant used to pay lump sum rent so that right of ownership may not lapse. Sometime rental income was also linked to the value of the real estates in Syria and Egypt.

Perhaps Turkey which has one of the longest history of Awqaf administration reached its peak during the Ottoman era, where Awqaf properties were estimated to have three quarters of the whole arable land in 1925. A Central Administrator of Awqaf was re-established after its abolition in 1924. Recently, a Waqf Bank and Finance Corporation have been set up to mobilize the Waqf resources and to finance various types of joint venture projects.

It is not out of place to mention here that the need for reform in many Muslim countries arises due to the fact that about one half (1/2) of the cultivable land in Algeria in mid nineteenth century was dedicated to Waqf. Similarly, in Tunis, one third (1/3) (1883), in Turkish Empire (3/4), (1928), in Egypt (1/7) (1935), in Iran about $15 \%$ (1930), of the whole arable land were endowed to Waqf. The accumulation of such extensive possession of land under Waqf had prompted many countries to introduce many reforms. Thus, Egypt enacted a law in L946 under which all family Waqfs were made temporary. Then, in 1952, a new decree was issued to the effect that no private Waqf can be created except for charitable purposes. Egypt which has a long history of Waqf management also allowed bank credit as a subject of Waqf endowment. In Syria, the question of family Waqf was prohibited in 1949. Yet, the model was permitted in Lebanon, although it only lasted for two generations. Afterwards, the ownership reverts to Waqf or heirs. Therefore, the Waqf was not considered to be an irrevocable legal transaction.

Furthermore, several reforms were introduced both in Tunisia and Algeria during the French colonial rule where the legal position of land was brought completely under French law and the sale of Waqf was recognized in practice. 
In India, the statutory control of Waqfs started with the passing of the Musalman Waqf Act of 1923 during the pre-partition days. During the post-partition era, several acts were enacted, and ordinances promulgated in Pakistan which was adopted in Bangladesh also. Whilst the Chief Administrators have assumed the administrative control and maintenance of Awqaf properties in Pakistan as well as in Bangladesh, in many, cases, the Awqaf properties only generate meager earnings which are insufficient for the upkeep of Waqf properties.

While permanent lease is giving insufficient income to maintain the property, Waqf has become one of -the sources of litigation particularly in Bangladesh. This calls for necessary reforms in the management and administration of Awqaf properties. Although there is a general tendency to have a state control over the management and administration of Awqaf properties, there are notable exceptions (i.e., Uganda, South Africa, Philippines) where Waqf is still designed as a purely private managed institution. This brief survey reveals that there is a considerable flexibility and scope for further reform in the development, management and administrations of Waqf properties in Muslim countries as well as in Muslim communities in non-Muslim country.

\section{WAQF ESTATES IN BANGLADESH: A BRIEF STATISTICAL OVERVIEW}

According to 1986 census of Waqf estate, there are 150593 Waqf estates in Bangladesh having multipurpose use. According to 1983 mosque census, 123,006 out of 131,641 mosques (93.4\%) in Bangladesh are Waqf properties. According to this census, Comilla Zilla has the highest number $(9,841)$ of Waqf estates followed by Mymensingh Zilla $(5,659)$ and Chittagong $(5,535)$. Bandarban Zilla has the lowest number of Waqf estates (201) proceeded by Rangamati Zilla (300). It was also observed that Bandarban Zilla had the lowest number of mosques according to 1983 census of mosques.

Out of the total Waqf estates, 97,046 are registered, 45,607 are verbal, and the rest 7,940 are Waqf by tradition. Comilla zilla has the highest number of registered Waqf $(15,171)$ followed by Mymensigh $(4,953)$. On the other hand, Satkhira Zilla has the least number of registered Waqf (41) followed by Khulna Zilla (43). Out of these large Waqf estates, only 13,200 Waqf estates are under the administrative control of Waqf Administrator out of which 10683 Waqf estates are of mixed nature. In the case of Waqf estates, in which more than 50 percent of the income is spent for religions and charitable purposes, those properties are treated as public Waqf. However, in the case of properties from which 100 percent income is spent for religious and charitable purposes, this is called as Waqf lillah'. Again, when a part of the income from Waqf is distributed among the family of the Waqif and his descendants, while the remaining part is spent for religious and charitable purposes, this is called as "Waqf-E-Awlad".

Waqf Administrator does not manage any Waqf property directly but oversees the management of the estate and controls the activities of the mutwallis. Each estate maintains its separate entity and is managed by a mutwalli. Some of the estates are managed by more than one "mutwalli" designated as "Joint mutwalli", while some others are managed by a group of persons designated as Mutwalli Committee. 


\section{THREE SECTOR MODELS OF SOCIAL ISLAMI BANK LTD: AN OVERVIEW}

Targeting poverty, Social Investment Bank Ltd is indeed a concept of 21st Century participatory three sector banking model in one: in the formal sector, it works as an Islamic Participatory Commercial Bank with human face approach to credit and banking on the basis of profit \& loss sharing; it is a Non- Formal Banking with the poor in non-corporate sector dealing with informal finance, Microcredit and Micro-enterprises that empower the family and create local income opportunities and discourage internal migration; it is a Social Development Bank intended to monetize the Islamic voluntary sector, committed basically to financing development and management of over 155,000 Waqf Mosque properties in Bangladesh as well as Non-Muslim Trust properties. SIBL is committed to implement the principle of participatory economy with human face approach to credit and banking on interest-free basis, which is in line with its objective to empower the family as the basic social unit. In his book "Islamic Capitalism and Finance: Origins, Evolution and the Future", Dr. Murat Cizakca described the introduction of Cash-waqf Certificate by Social Islami Bank Ltd (previously known as Social Investment Bank Ltd), a three-sector banking model operationalized since 22 November 1995 in. Dhaka, as "The Mannan Model" (Bangladesh). It is worth quoting his following observations.

This bank floated the cash waqf certificate as a financial instrument in 1997. The three sectors are a formal incorporated bank, a non-formal bank focusing primar-ily on micro investment and microenterprises and finally a voluntary banking sector focusing on cash waqf certificates. Thus, this institution represents a synthesis of the Western corporation with cash waqfs as well as microfinance. Mannan argues that issuance of cash waqf certificates and thus collecting cash from the public breaks the age-old monopoly of the rich for waqf establish $\neg$ ment. Now, indeed, for the first time small savers can contribute to the estab $\neg$ lishment of a waqf. Theoretically the number of cash waqf certificate holders can now be infinite. Indeed, each certificate is issued in terms of a small denomination worth Tk.1000 (US\$21 only). It is therefore affordable to a large section of the population. Moreover, to make contributions even more affordable, cash certifi $\neg$ cates can also be purchased in instalments. Cash waqf certifi $\neg$ cate holders, however, have no voting power and after identifying the purpose of the waqf they want to contribute, they entrust its management to the bank." It seems that the basic idea of the Mannan model, that is, expanding the number of founders infinitely, is catching up (Cizakca, 2011).

\section{CASH-WAQF CERTIFICATE OF SOCIAL ISLAMI BANK LTD (SIBL) AS SOLUTION OF OTTOMAN DILEMMA}

As mentioned earlier, the floating of Cash-waqf Certificate as a financial instrument by Social Islami Bank Ltd (SIBL) (formerly known as Social Investment Bank Ltd) in 1997 is an innovation in the history of Islamic Finance. It has settled the age-old controversy among scholars concerning the concept of perpetuity and inalienability associated with waqf property since its implementation during the Ottoman Empire in the early 15th century. The issuance of Cash-waqf Certificate by Social Islamic Bank Ltd solved the Ottoman dilemma for the first time in history 
by removing the twin barriers of waqf to perpetuity, and immovable property endowment as well as Islamic injunctions on charging interest on loan and provided an opportunity for Muslims to invest in religious, educational or other social development.

\section{CASH-WAQF CERTIFICATE AS MULTI-DIMENSIONAL INVESTMENT STRATEGIES}

\subsection{Cash Waqf Certificate: Its objectives}

(i) To provide Banking services as facilitator to create Cash Waqf and to assist in the overall management of Waqf.

(ii) To assist in mobilization of social savings by creating Cash Waqf with a view to commemorate alive or deceased parents, children and to strengthen the integration of the family relationship of the well-off people and the rich.

(iii) To increase social investment and to transform the social savings into social capital.

(iv) To benefit the general public especially the poor sections of the people out of the resources of the rich.

(v) To create awareness among the rich regarding their social responsibilities to the society.

(vi) To assist in developing social capital market.

(vii) To assist in overall development efforts of the country and to make a unique integration between social security and social peace.

(viii) To empower people at the grass root level and to open up new frontiers of human freedom that includes freedom from educational, social and economic deprivations.

\subsection{Cash Waqf Certificate: Connecting People at the Grass Roots}

Historically, Waqf was the privilege of the rich. However, under the Cash-Waqf scheme, anybody can participate. Globalization of Cash-Waqf would eliminate the distinction between the rich and the poor in terms of who gets to participate in social causes. Different Simulation Models can be built up on various assumptions for mobilization of Cash-Waqf Fund. For example: assuming mobilization of CashWaqf of one US dollar per Muslim in one month amounts to accumulation of 1.6-billion-dollar Cash-Waqf fund globally, 260 million in Indonesia, 160 million in Bangladesh, 176 million in Pakistan, 80 million in Turkey, 30 million US dollar in Malaysia and so on.

\subsection{Cash Waqf Certificate: Empowering Multigenerational Family Heritage}

Consider: yourself, your parents, your grandparents - that is at least one hundred years of your family history.

Consider: Yourself, your children, your grandchildren - that is next hundred years of your family's future history. In this way, an individual can chain easily link himself for two hundred years in the family Chair. The extended present - a family chain: 
Table 1. The extended present- a family chain:

Grandparents-parents-self-children-grandchildren 200 years

\begin{tabular}{llll}
\hline \multicolumn{1}{c}{2000 (Past) } & \multicolumn{1}{c}{2100 (Present) } & \multicolumn{1}{c}{$\mathbf{2 2 0 0}$ (Future) } \\
\hline Beneficiaries of & SIBL Offers & Family Stability and \\
The Continued & - Output & sustainable opportunities \\
Charity/Waqf & - Employment & Future beneficiaries of \\
& - Income & - & continued Charity/Waqf \\
& - & Management of & \\
& - & Continued Charity/waqf & \\
\hline
\end{tabular}

Social Security, Social Peace and Empowerment of a family heritage (Three Dimensional benefits)

\subsection{Cash Waqf Certificate: Guidelines}

The guidelines, governing the operation of the Cash Waqf Certificate or Cash Waqf endowment are as follows:

1. Cash Waqf shall be accepted as endowment in conformity with Shariah. Bank will manage the Waqf on behalf of the Waqif.

2. Waqifs are done in perpetuity and the Account shall be opened in the Title given by the Waqif.

3. Waqif will have the liberty to choose the purpose(s) to be served either from the list of 32 purposes identified by SIBL as given below or any other purpose(s) permitted by shariah.

(i) Improving the conditions of absolutely poor living below the poverly line

(ii) Rehabilitating physically handicapped and disadvantaged group of people

(iii) Rehabilitating beggars.

(iv) Rehabilitation of destitute women

(v) Upliftment of urban slum dwellers

\section{A. Education \& Culture:}

(i) Education of orphans i.e. supplying - books free of cost; or preventing ChildLabor.

(ii) Expansion and development of appropriate education for skill development

(iii) Informal education facilities of children at home (i.e. mother's educational program, children literature)

(iv) Physical education and sports facilities

(v) Supporting local culture and heritage and art promotion

(vi) Conducting Dawah activities

(vii) Supporting education of deserving students in the form of scholarship

(viii) Supporting vocational education in general

(ix) Supporting education of inaccessible and neglected area.

(x) Financing specific Madrasha/School/Colleges of a particular area.

(xi) Educating deserving descendants.

(xii) Supporting any projects in the area of education, research, religious and Social services in the memory of father, mother and any descendants.

(xiii) Establishing educational chair.

(xiv) Village health care and sanitation 


\section{B. Health \& Sanitation:}

(i) Supplying pure drinking water (to households, schools, mosques, slums, etc.)

(ii) Establishing hospitals, clinics, health care programs especially for the poor.

(iii) Health research grants and research in particular disease.

\section{Social Utility Service:}

(i) Settling disputes (e.g. Village litigation)

(ii) Providing legal aid to deserving women to establish their lawful rights.

(iii) Assist in arranging dowry less marriages to poor girls.

(iv) Maintenance of public roads and tree plantation in the village

(v) Providing assistance to peace loving non-Muslims and solving their Problems

(vi) Creating social awareness to prohibit gambling and other social vices, such as, theft and other anti-social activities

(vii) Construction, installation and development of public utility services

(viii) Maintenance of a specific mosque(s) with an income generating project(s)

(ix) Maintenance of a specific graveyard with an income generating project(s)

(x) Maintenance of a specific Eidga(s) with an income generating project(s)

Thus, the 32 purposes under 4 major fields like (1) Family Rehabilitation (2) Education \& Culture (3) Health \& Sanitation (4) Social Utility and (5) Others are considered as General Guidelines for distribution of profit of Cash waqf A/Cs. In the case where only fields(s) for distribution of profit are mentioned without specifying the name of the beneficiary(s) whether individual(s) or institution(s), those Cash Waqf will be treated as General Cash Waqf and the profit of those A/ Cs will be spent for welfare of mankind in the field of (1) Family Rehabilitation (2) Education \& Culture (3) Health \& Sanitation (4) Social Utility and (5) Others. On the other hand, Waqif may choose distribution of the profit to any specific individual(s)/ institution(s). Those A/Cs will be treated as Specific Cash Waqf, the profit of those A/Cs will be sent to the beneficiary(s) as specified by the Waqif (Mannan, 2011). Any other lawful purposes considered appropriate may be added.

4. Cash Waqf amount will earn profit at the highest rate offered by the Bank from time to time.

5. The Waqf amount will remain intact and only the profit amount will be spent for the purpose(s) specified by the Waqif. Unspent profit amount will automatically be added to Waqf amount and earn profit to grow over the time.

6. Waqif may also instruct the Bank t6 spend the entire profit amount for the purpose specified by him/ her.

7. Waqif will have the opportunity to create Cash Waqf at a time. Otherwise, he/ she will declare the amount he/she intends to build up and will start with a minimum deposit of Tk. 100/ = one hundred only (or equivalent foreign currency). The subsequent deposits shall also be made in hundred or in multiple of hundred.

8. Waqif shall also have the right to give standing instruction to the bank for regular realization of Cash Waqf at a rate specified by him/her from any other a/c maintained with SIBL. 
Linking Islamic Commercial and Social Finance with Special Reference to Cash-Waqf as New Strategy of Interest-Free-Micro-Credit for Family Empowerment of The Poor Towards Establishing

9. Cash Waqf shall be accepted in specified endowment Receipt voucher and a certificate for the entire amount shall be issued as and when the declared amount is built.

10. The Principles and Shari'ah based rules of Cash Waqf Account are subject to amendment and review from time to time.

\section{CASH-WAQF AS A STRATEGY OF INTEREST-FREE MICRO-CREDIT AND MICRO-ENTERPRISES TO FAMILY EMPOWERMENT}

Credit can transfer power to powerless and help alleviate poverty. It can reinforce power of the powerful and help in concentration and inequitable distribution of income and thus aggravating the poverty. Seen from this prospective, it can empower a family or disintegrate it. The family is a basic foundation of human society. The foundation of a family is laid through marriage and the relationship between husband and wife is viewed in Islam as that of a garment and its weaver; it is a civil contract, imparting mutual rights and duties. Christianity and Hinduism also have the same position, in which the family remains a bed-rock of a society. Hence, the management of Micro-Credit and Micro Enterprise Financing have profound impact on micro economic sociology of the family involving the individual in the family, organization and activity within the family and the relationship among family member consisting mainly of husband, wife and children as well as macroeconomic sociology of the family involving interchange and transactions between the family and society in which it operates. Because family are linked together with other social structure in extended family, neighborhood, villages, communities, kinship groups. The family performs a vital part of the function essential to the individual and group life.

Despite the fact the corporation replaces the family in the production of mass consumption goods and services in the industrial society, the family still plays an important part in the economic functions. Many farms that were operated as family enterprises, new enterprises in business and industries often began as family enterprise. Often capital came to be drawn from family holdings and business expanded by family financing. Most of small and medium-scale business and industries in the developing countries have been family enterprises.

Apart from this, family is one of the major consumer units in any society. One way to create new market is by changing the habit of the consumers through efficient marketing method: Installment of buying and selling is an important aspect of family economy inter-change. Similarly, rotating family saving schemes can be used in diverse family economy interchange activities. It is argued that conventional micro-credit programs of Non-Banking Financial Institutions as well as Non-Government Organizations (NGO) is either consciously or unconsciously affecting the family adversely. Evidence suggests that in many cases, family as a basic unit of the society is threatened due to the very nature of credit program which is directed towards decomposing the family for its eventual disintegration. Seen from this perspective, family empowerment through micro-credit does represent a significant shift in paradigm. This linking credit to social values will have far reaching theoretical and operational implications both at micro and macro-economic levels. In Bangladesh, there is at least 15 million families living 
below poverty line. They can hardly enter into market. (Fourth Annual Report 1998, SIBL, p. 10)

\subsection{The Frontiers of Family Empowerment Credit Programs}

The family empowerment credit programs is predominantly come under Nonformal Banking. Non-formal Banking deals with informal finance in noncorporate sector. The popular view of in-formal Sector activities is that they are primarily those of petty traders, street hawkers, shoeshine boys and confined to employment on the periphery of the main urban areas. On the contrary, informal activities are the way of doing things, characterized by: (i) ease of entry; (ii) reliance of indigenous resources; (iii) family ownership of enterprises; (iv) small scale of operation; (v) labor intensive and adapted technology; (vi) skills acquired outside the formal school system; and (vii) unregulated and competitive markets.

One important characteristic of the formal sector is its relationship to the government. Economic activities are formally and officially recognized. They obtained direct benefit of access to credit, foreign exchange concessions, work permit and a formidable list of benefits that reduce the cost of capital in relation to that of labor. This is partly induced by its privileged access to resources, the formal sector is characterized by large enterprise sophisticated technology, high wage rates, high average profits and foreign ownership.

The informal sector on the other hand, is often ignored and in some respects harassed by the authorities. Enterprises and individuals within it operates have no access to the formal credit institutions. The evidence suggests that the bulk of employment in the in-formal sector is economically efficient and profit making, though small in scale. These non-corporate sectors which covers small scale producers and enterprise traders, small farmers and low income and middle groups of people account for $30-70 \%$ of the labor force in some developing countries. This is where Islamic Bank must make a conscious and planned intervention. The difference of wealth and income between urban and rural area draws migrants towards the urban concentrations, not to the spread of wealth. (Fourth Annual Report 1998, SIBL p. 10-11)

\subsection{Family Empowerment Credit Programs: Comparative Review}

Evidence indicates that successful family empowerment credit program or group lending schemes, under Non-formal Banking of Social Investment Bank Ltd. works well with groups that are homogeneous and jointly for liable for defaults. The practice of denying credit to all group members in case of default is found to be most effective and least costly way of enforcing joint liability. Group lending arrangements without collateral are less subject to the dangers of portfolio concentration because Bank is diversifying lending by serving a varied clientele in different areas under its family empowerment credit arrangement. Bank also is ensuring joint liability of wife and husband in case of lending to family or groups of families. It humanizes family and discourages internal immigration. Any attempt to decompose family through various credit and financing schemes in its ultimate analysis bound to generate the forces of disintegration of families, 
internal migration, child delinquency, social alienation and social conflict. Any credit program which does not manage its socio-economic consequences cannot alleviate poverty. Besides, Bank has already introduced Rotating Family Savings and Credit Net and Group installment credit Scheme for any group of individuals. In the light of this experience, SIBL is also in the process of developing program to assist Agriculture co-operatives in providing tailor-made credit package to achieve their objectives in rural settings.

It is apparent from the operations of Social Investment Bank that it works on a fundamentally different approach and socio-economic philosophy compared to other major Banking, Financial and Non-Banking Financial Institutions (NBFI) i.e. Grameen Bank and Non-government Organization (NGO) operating in Bangladesh for alleviation of rural and urban poverty. While Grameen Bank in Bangladesh is aiming for women's empowerment (More than 95\% of its client are women) and most of the other NGOs intend to empower the poor, as opposed to rich, they are heavily dependent on foreign loans, aids and grants and work on high interest rate basis on implicit assumptions of social class conflict, whilst the Social Investment Bank intends to empower the family as a basic social unit and generate its own internal resources.

SIBL aims to engage both men and women, regardless of their financial abilities, in poverty alleviation programs and work on participatory basis on the implicit assumptions of social class harmony. It evidently implements its programs with economic and social transparency without dependent on foreign aid or grants. In fact, a real value added to this bank lies in its power of new ideas involving not just a change in economic system but a change in conventional pattern of thinking for socio-economic well-being of people at the grass-root level, strengthening family values and the moral foundation of the society.

By teaching the women to be 'independent' and 'defiant' with their husbands, voluntary organizations are presumed to undermine the family. Religious groups argued that the NGOs' work with woman was a form of cultural interdiction imposed through Western materialistic and secular values. When peoples' identity and culture are threatened, they often react by going back to their roots. (Fourth Annual Report 1998, SIBL p. 11)

\section{GLOBAL MOBILIZATION OF CASH-WAQF AND ESTABLISHMENT OF WORLD SOCIAL BANK}

Upon presentation of the concept of Cash-waqf Certificate endowment by the author at the Third Harvard University Forum on Islamic Finance organized by Harvard University, USA held on October 1, 1999, this concept has already been operationalized in Indonesia (2002), Bangladesh (2003), Malaysia (2007) and Memphis, USA (2007) and it is gaining ground day by day. It is pertinent to mention that when I was sitting Chairman of Social Islami Bank Ltd (SIBL) (previously known as Social Investment Bank Ltd), "Dhaka Declaration Of Intent" was made between Social Islami Bank Ltd and three distinguished Indonesian bankers dated 8 August 2000 in which establishment of World Social Bank with its Headquarter in Jakarta was proposed. A copy of which is attached. All three distinguished 
Indonesian Bankers opened token Cash-waqf account with Social Islami Bank in Dhaka in 2000 and these accounts are still operational.

As noted earlier, all the six Islami Banks in Bangladesh have already adopted this concept and mobilization cash-waqf fund for social investment. In a recent book of the author entitled, "Cash-waqf: Living by giving and sharing", it has been demonstrated as to how one-dollar (US) cash-waqf endowment can create World Social Bank for providing micro-credit to the poor at zero rate interest. Cash-waqf Certificate Movement has begun (i.e. mobilization of Cash-waqf fund from every Muslim, rich or poor, say from one US dollar to any amount, locked in forever for investment.

According to a recent report published by Pew Forum on Religion and Public Life, USA (2007), the global Muslim population stands at 1.6 billion, meaning that nearly 1 in 4 people in the world practice Islam. The report also presents a portrait of the Muslim world that might surprise those who read it. For instance, Germany has more Muslims than Lebanon, China has more Muslims than Syria, Russia has more Muslims than Jordan and Libya combined, and Ethiopia has nearly as many Muslims as Afghanistan. Islam is world's second largest religion behind Christianity, which has an estimated 2.1 billion to 2.2 billon followers. The same study identified one fifth of the world's Muslim population is living in countries, where Islam is not the majority religion.

Based on these statistics, various Simulation Mode1s can be constructed based on different assumptions. Assuming mobilization of Cash- Waqf of one US dollar per Muslim in one month amounts to accumulation of about 1.6-billion-dollar cash-Waqf fund globally, 224 million in Indonesia, 160 million in Bangladesh, 154 million in Pakistan, 70 million in Turkey, 25 million US dollar in Malaysia and so on.

Muslims are the only major religious group projected to increase faster than the world's population as a whole estimated change in population size, 2010-2050 is Muslims: $73 \%$, Christians: 35\%, Hindus: 34\%, Jews: 16\%, Folk Religions: 11\%, Unaffiliated: $9 \%$, Other Religions: $6 \%$, Buddhists: -0.3 , and 35\% growth in overall global population.

"Cash-Waqf" funds cannot used directly to finance projects. The fund will be invested in viable ventures and the returns from projects will be used to finance projects. The fact is that the challenge of the Muslim World in the fields of education, science and technology, health and research as well as the level of general economic deprivation of the masses have reached at general level of global crisis. An average of hardly $4 \%$ of the GNP of Muslim World spent on education against that of $7 \%$ on defense. At present, the Muslim world has the lowest number of manpower in the field of science and technology. "On a global scale, three billion people live on less than $\$ 2$ a day, 1.3 billion do not have clean water, 130 million children unable to access education, and 40,000 children die every day because of hunger-related diseases. Within this deprivation is another dimension: hundreds of millions of girls and women whose lives are diminished and shortened by inadequate economic means and discrimination in social status and medical attention." (Sen \& Wolfensohn, 1999)

Viewed from this perspective, "Cash-Waqf" finance can be seen as a process of expanding and unfolding the frontiers of human freedom from economic educational and social deprivations. In addition, Awaqf properties are estimated 
to run into billions of dollars worldwide, yet hitherto there have been no systemic attempts to leverage this invaluable pool of assets to raise liquidity; to develop the Waqf properties and services for benefit of human societies through floating Waqf Development Bonds by Islamic Banks as intended.

Furthermore, there is an increasing demand for world class wealth management service for the fast-growing Islamic wealth management industry belonging to Muslim individuals and families. According to the Boston Consulting Group, wealth of these families is reported to be in excess of staggering US \$10.2 trillion. Based on the feedbacks and inter-actions with their clients and investors, many private bankers stressed there is a huge demand for Shariah-compliant wealth management products and services (Azmi, 2007).

Thus, viewed from these perspectives, the mobilization of Cash-waqf fund on global scale, development of Awaqf properties and management of new Islamic wealth, the establishment of World Social Bank with its Headquarters in any major Muslim countries will create great opportunities for development of Commonwealth of Muslim countries and communities in Non-Muslim countries with a partnership of both public and private sector for serving humanity at large, thereby paving the way for Social Peace in the world. Since one fifth of the world Muslim population is living in countries where Islam is not the majority religion, there is a need to form Commonwealth of Human Communities for the sake of peace. Nation-state concept has generated crisis, conflict and war in the affairs of mankind, indeed. Cash-waqf fund can be spent for the welfare of non-Muslim also.

In this context, the registration of the Global Cash-Waqf Fund Trust on May 12, 2011 under the Trust Act of 1882 in Bangladesh is an important milestone towards establishing the proposed World Social Bank. A first step is always significant milestone towards journey of thousand miles. The following flow-chart unfolds the linkage of key-concepts and ideas concerning establishment of the proposed World Social Bank as the collective response of Islamic Ummah in alleviating poverty.

\section{ACTION PLAN: THREE PROPOSALS}

Taken all in all, we may submit the following three proposals for considerations of this conference.

i. This conference may call upon the Bank Indonesia to give institutional leadership for mobilization of Cash-waqf at national and global scale for the establishment of World Social Bank as a strategy for providing interest-free Micro-Credit for Family Empowerment of the Poor at the grass root level.

ii. This conference may call upon to circulate the proceeding of this conference to the all governors of Central Banks of 57 Muslim countries so that an Institutional Taskforce be formed to materialize the establishment of World Social Bank soonest possible.

iii. This conference may call upon Muslim minorities in non-Muslim countries to take initiatives to mobilize cash-waqf fund at local, national and global scale and efforts should be made to connect individual initiatives, thereby laying the foundation to form Commonwealth of Human Communities for the benefit of all the people irrespective of cast, creed and religion. 


\section{CONCLUDING OBSERVATIONS}

Evidence suggests that Waqf engendered significant contribution to social development of Islamic Ummah over time. The Cash Waqf Certificate Scheme is an epoch-making event. Since the aforementioned Cash Waqf is managed by the Bank, it has its transparency and accountability, it is a perpetual deposit and its profit can be invested in a wide spectrum of social investment. Bank shall manage Cash- Waqf on behalf of the Waqif. This ensures appropriate utilization of the fund of the Waqif in terms of its goals and objectives involving diverse social investment activities having enduring value which in its ultimate analysis will create a base for perpetual social capital and help developing, credit program that reinforces family values and stimulate civil caring society.

The Holy Quran has emphasized the virtues of charity in life on earth and life hereafter. The Cash Waqf Certificate offers an opportunity to get the divine blessing and to have a rewarding social and spiritual experience and internal peace. The floating of Cash-Waqf Certificate as a financial instrument by Social Islami Bank Ltd. in 1997 is an innovation in the history of Islamic finance and solved the Ottoman dilemma by removing the twin barriers of waqf to perpetuity as well as Islamic injunctions of interest on loan. It can help monetizing Islamic Voluntary Sector, accumulation of Social Capital and National wealth, implementing strategic social investment program that reinforces family values, family heritage empower people at grass roots and stimulates economic, social and moral foundation of a caring society. Cash-Waqf Certificate provide new opportunities to transfer liquid asset and make connection with one another on a global scale leading to establishment of World Social Bank a new strategy of interest-free micro-credit for the empowerment of the poor to irrespective of caste, creed and religion. Lastly, it is stressed that Bank Indonesia should give institutional leadership to materialize the establishment of World Social Bank. Cash-waqf can be spent for the benefit of non-Muslims also.

\section{REFERENCES}

Ibrahim, H., Amir, A., \& Masron, T. A. (2013). Cash waqf: An innovative instrument for economic development. International Review of Social Sciences and Humanities, 6(1), pp. 1-7.

Khademolhoseini, Majid. (2008). Cash-Waqf: A New Financial Instrument For Financing Issues: An Analysis Of Structure And Islamic Justification Of Its Commercialization. Imam Sadiq University.

Mannan, M.A. (Cash-waqf) Model (Bangladesh) in Cizakca, Murat, Islamic Capitalism and Finance, Origins, Evolution and the Future. Edward Elgar, pp. 114117.

Mannan, M. A. (2011). Cash Waqf, Living by Giving and Sharing. dari http://www. drmannan. net/cash-waqf-living-by-giving-and-sharing-2/. (Accessed on November 20, 2017)

Mannan, M. A. (1999). Cash waqf certificate-an innovation in Islamic financial instrument. In Global opportunities for developing social capital market in the 21st century voluntary sector banking, paper presented to the Third Harvard University Forum on Islamic Finance, Cambridge Massachusetts, USA, October 1, 1999(Vol. 1). 
Mannan, M. A. (1998). New Frontiers of Islamic Banking in the 21st Century with Special Reference to Informal and Voluntary Sector Banking. Paper presented in the Second Harvard University Forum on Islamic Finance, Islamic Finance into the 21st Century, Harvard University, Cambridge, Massachusetts, October 9-10, 1998, pp. 275

Mannan, M. A. (2011). Cash-waqf: Living by Giving \& Sharing Towards Establishment of World Social Bank: A New Strategy of Interest-Free Micro-Credit to the Poor and Profitable Investment Option for the Rich. Mannan Charitable Trust (HMCT), Dhaka, Bangladesh, pp. 46-47.

The Daily Star, Dhaka, Tuesday, January 19, 2016

Cizakca, Murad. (2011). Islamic Capitalism and Finance, Origins, Evolution and Future. Edward Elgar, USA, pp. 114-115.

Sen, Amartya and Wolfensohn, James D. (1999). Poverty, Development and the People. in Daily Independent, Dhaka, 12th May 1999

Global Wealth Management. (2007). New Trends and Perspectives by Wan N. Wan Azmi, Special Report by Labuan Offshore Financial Services Authority, Malaysia, Finance Newsletter, Nov. 2007, Issue 2. 


\section{APPENDIX}
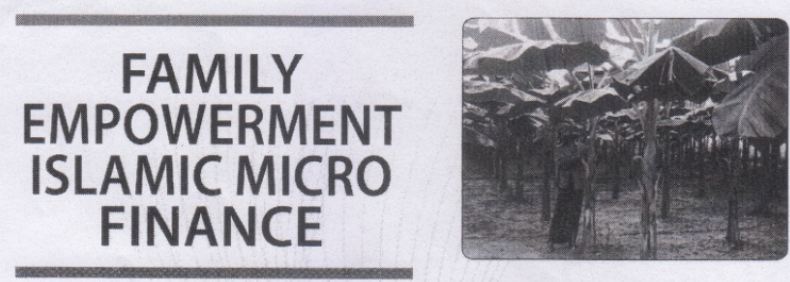

Financing to:

Md. Sakander Ali

Financed by:

Gobindogonj Branch

Social Islami Bank Ltd.

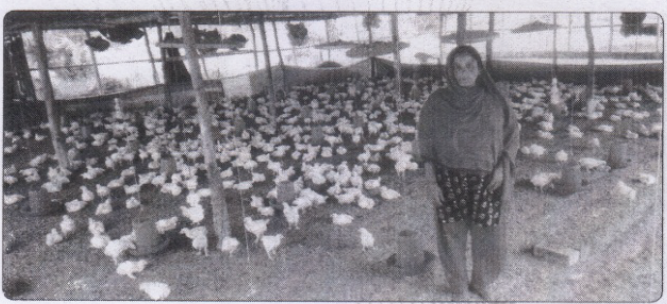

Financing to:

Mst. Helena

Financed by:

Dupchanchia Branch

Social Islami Bank Ltd.

Financing to: Md. Bodiuzzaman

Financed by: Dupchachia Branch Social Islami Bank Ltd.
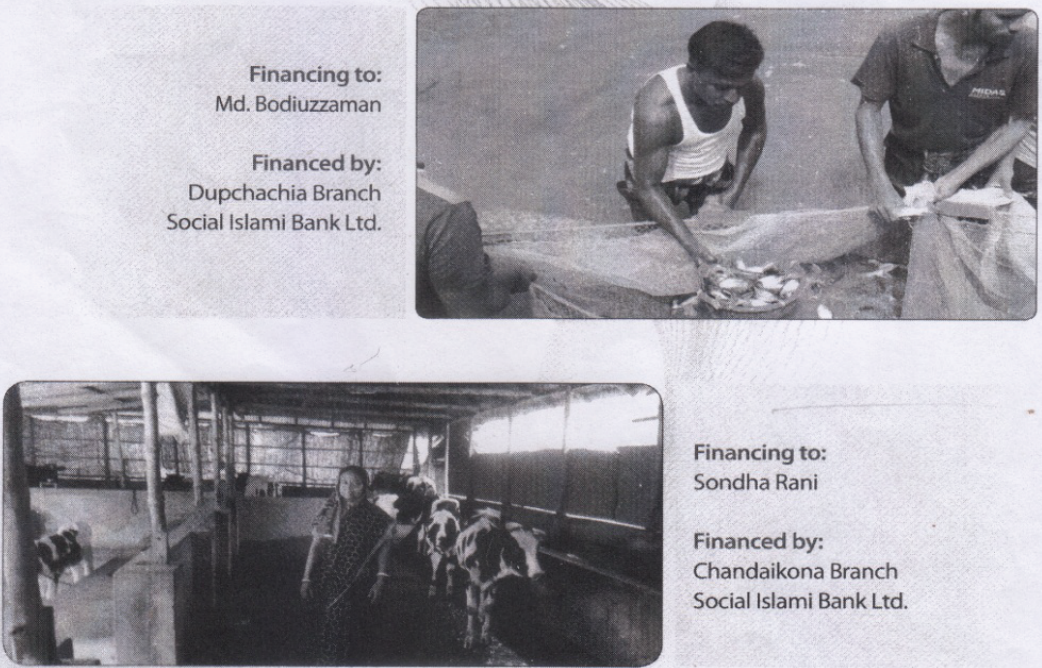

Financing to:

Sondha Rani

Financed by:

Chandaikona Branch

Social Islami Bank Ltd.

228

ANNUAL REPORT 2016

Source: Annual Report 2016, SIBL, Page-228

Figure 1.

Family Empowerment Islamic Micro Finance by Social Islami Bank Limited 
Linking Islamic Commercial and Social Finance with Special Reference to Cash-Waqf as New Strategy of Interest-Free-Micro-Credit for Family Empowerment of The Poor Towards Establishing

In the name of Allah, Most Gracious and Most Merciful.

"Man's work ends upon his death except three things: (a.)Contribution to Knowledge, (b) On-going charity and (c) Faithful child."(Al-Hadith)

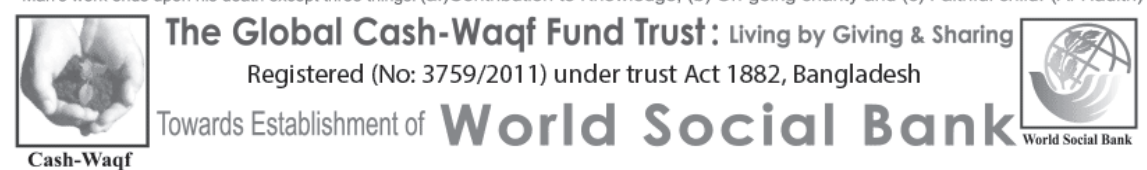

A New Strategy of Interest-Free Micro-Credit to the Poor and Profitable Investment Option for the Rich

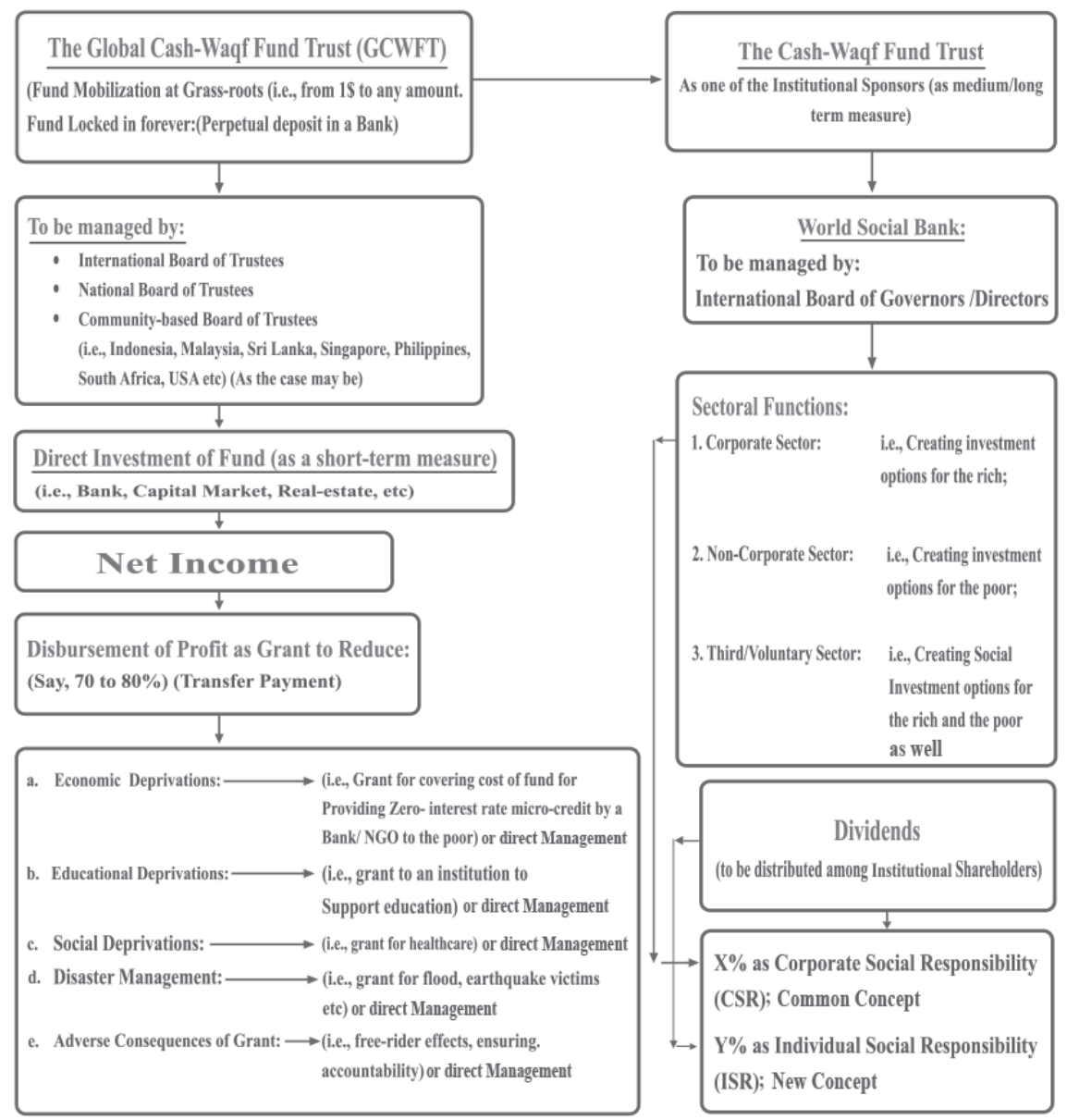

Prepared by: Prof. Dr. M. A. Mannan

Founder Chairman: Social Islami Bank Limited (SIBL) Dhaka, Bangladesh \& House of Mannan Charitable Trust (HMCT), Bangladesh. Email: hmct2004@yahoo.com;web:www.mannantrust.org

Figure 2.

The Global Cash-Waqf trust Fund 


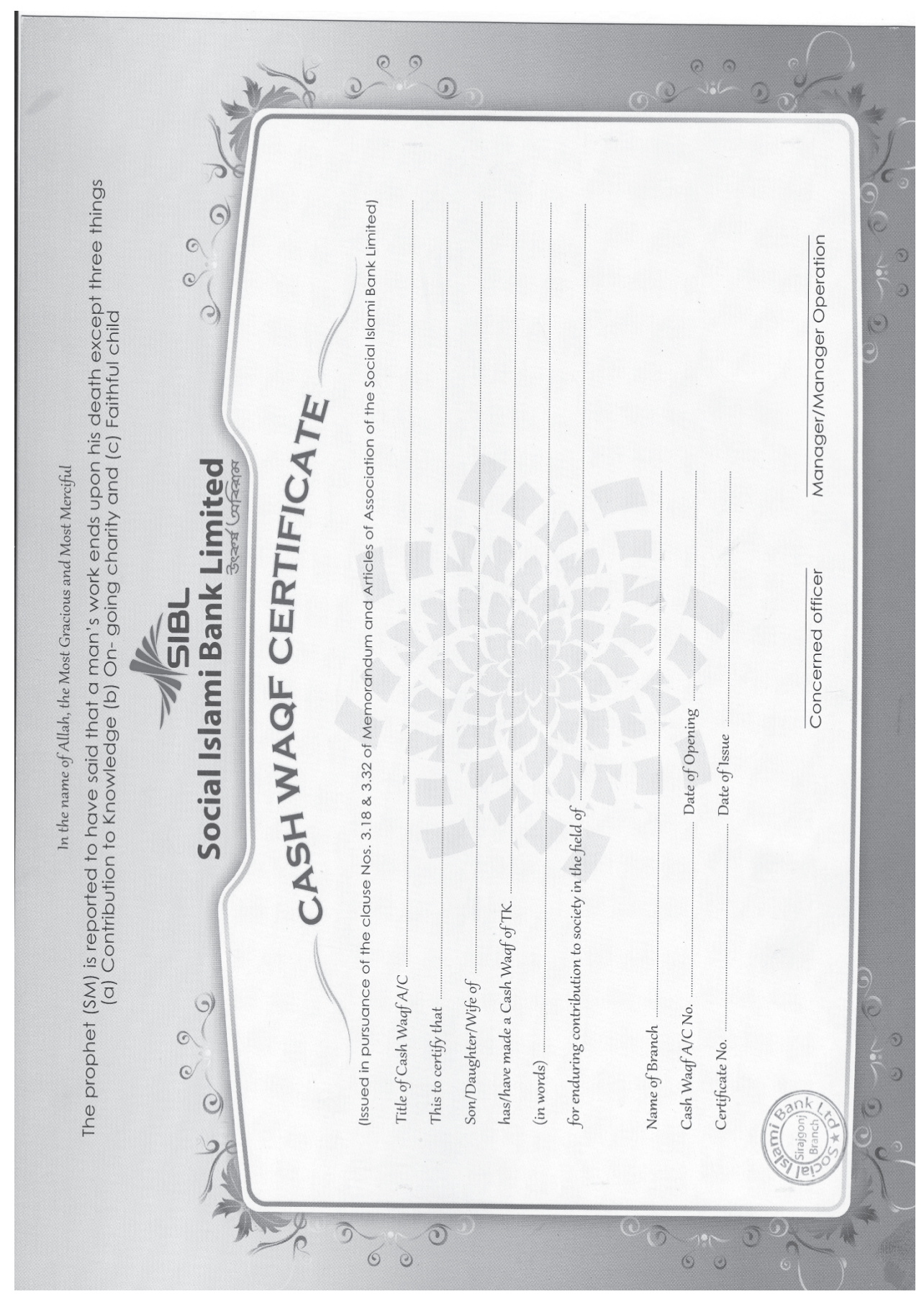

Figure 3.

Sample of Cash-waqf Certificate as issued by Social Islami Bank Ltd (SIBL) in Bangladesh in 1997 


\section{DHAKA DECLARATION OF INTENT}

BETWEEN

Social Investment Bank Limited

A Three Sector Unique Model Joint Venture Bank

(Working Together For A Caring Society)

15, Dilkusha Commercial Area, Dhaka-1000, Bangladesh,

AND

Indonesian Bankers, all Messrs.

1. Dis. AMIR RADJAB BATUBARA

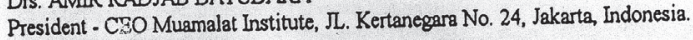

2. WINARTO SOEMARTO

Formet President, Bank Negara Indonesis Batavia Building, Jakarta, Indonesia.

3. LUKMAN NUL HAKIM

Former Mansging Director, Bank Dagang Negara, JL. Metro Podok Indah No. 31, Jakarta, Indonesia,

members of discussion group of Muamalat Institute.

Second Party

Whereas Social Investment Bank LImited (First Party), Head Office, 15, Dilkusha Commercial Area, Dhaks-1000, Bangladesh is a Scheduled Commercial Bank, a Three Sector Joint Venture Bank is committed to develop a caring society by boosting up economy, eliminating poverty, empowerment of amily and communities of Islamic Ummah and consolidating its economic potentialities and power as a unique solution to mankind. As per corporate objective, the bank is committed to achieve business and development objectives.

and,

whereas Indonesian Bankers (Second Party), are engaged in discussion group for developing Shariah Banking and shariah products.

whereas both parties have expressed their wishes to make an agreement for mutual cooperation for whereas both partes have explas an innovative shariah based product of Social Investment Bank Limited and planning in establishing a "World Social Bank" based on shariah in the private Sector, it is, therefore, agreed as follows :-

1. Both parties agreed that there is a need for banking beyond the frontiers of market (i.e. need for nonformal banking involving Family Empowerment Micro credit and Micro-enterprises programme) to the need for Voluntary Sector Banking (i.e. strenghen farly as a basic turt sector activities such as Awegf, Property Development Fund etc.) is also needed. Both parties agreed to set-up a branch or an organizational vehicle in Jakarta as soon as possible for starting functioning there covering three sectors of economy on the basis of Social Investment Bank Limited Model of Banking.

2. Both parties agreed that there is urgent need of Global Mobilization and creation of Cash Waqf Fund for Human and Social Infrastructure of the Islamic Ummah mainly through sale of Cash Wagf Fund for thum Certificate to accommodate need. of the Muslury and beyond. The lack of human and social capital technology, health and research in the 21 st century and beyond. The lack on health and research have infrastructure and the commitment of the Ummah in the field of education, health and research hy placed Muslims in the darkness of illiteracy, ignorance and poverty.

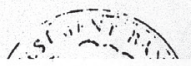

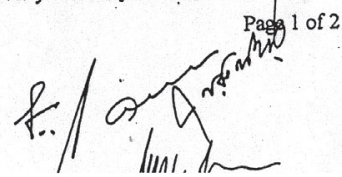

Figure 4a.

Dhaka Declaration of Intent between SIBL and Distinguished Indonesian Bankers 
Page : 2

10 explore and help development of worldwide Islamic socio-economic and financial infrastructure, particularly in the ares of joint venture projects for an eventual development and establishment of 'World Social Bank' based on shariah in the private sector with its Head Quarter proposed in Jakarta or any suitable host country for global mobilization of social savings and investments that Jakarta or any suitsble host country for global mobiliation of social sesponsibilities of civil society at the reinforce basic family and societal values and stimula civic tespon must address the issues involving grass-root level. The proposed Word Social Bank of islamic Ummah must adde fund for establishment of globalization of poverty. Privale Sector of Islamic Ummah should forward to create fund for establishent of this Bank

A creative Task Force may be established to explore the possibilities of :

i) Establishing Joint-venture Islamic Ummah Corporation.

ii) Re-writing a New participatory Economics by desecularizing consumption, production and distribution process. Link credit to culture, social goals and social assignments.

iii) Setting up Education Trust or Creating Endowment for joint research massive translation of ind non-Muslim of every academic disciplines into local significant works/books of Mushim and non-Mosing muslim Scholars, setting up schools of alternative/oriental medicises.

4. Both the parties will jointly develop economic and trade cooperation, promote training programs to enhance the professional and institutional capacity of the Bank and their staff members as well as enhance the professional and institutional capacity of the Bank and the semittance, information exchange, explore other areas of economic and cultural cooperation such as remittance, inforis and another muslims communities and human societies subject to local laws.

5. Both the parties stressed the need for acquisition of knowledge and adapting contemporary Both the parties stressed the noed considering the fact that knowledge is a heritage of mankind. excellence in science and technology considering thation due to its historical record and emphasis on The revival of Islam will prevent the clash of civilization due to its historical cecontribution to world total welfare on man and humanism, Islamic civilization made an immense contribution to world civilization over thousand years during medieval period and made a permanent contribution to peace.

6. The Dhake deciaration of intent is made on Tuesday, the 8th August, 2000 (5th Jamadiul Awal $1421 \mathrm{H}$.).

IN WITNESS WHEREOF The partics have executed this declaration of intent on the day, month and year above mentioned.

Elrst Party

1. PROF. DR. MA MANNAN

Founder Chairman

Soclal Investment Bank Ltd. Head Office 15. Dilkueh C/A, Dhakas -1000 , Bengledesh.

2. M.M. NURUL HAQUE

Managing Direccor

Soclol Investment Bank Ltd, Head Office 15, Dilkurha CIA. Dhake-1000, Bengladesh.

Second Party

1. Drs. AMIR RADJAB BATUBARA

Prosidont - CEO Muamalas Intitute

I. Kertanegars No. 24 Jal

Former President

Bark Negara Indonesia 46, Baxavis Building

Jakerta indonesia.

3. LUKMMAN NUL HAKIM

FUKMMAN NUL HAKIM

Bank Daqang Negara

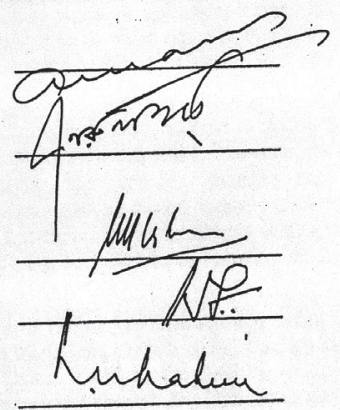

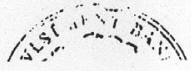

Figure $4 b$.

Dhaka Declaration of Intent between SIBL and Distinguished Indonesian Bankers 
Linking Islamic Commercial and Social Finance with Special Reference to Cash-Waqf as New Strategy of Interest-Free-Micro-Credit for Family Empowerment of The Poor Towards Establishing

This page is intentionally left blank 